\title{
Socio-economic Disparity Problems and Convergence Policy in the EU States
}

\author{
Elena Dubra \\ Dr.OEC., Professor, University of Latvia Faculty of Business, Management and Economics, Latvia
}

\begin{tabular}{|c|c|}
\hline & ABSTRACT \\
\hline $\begin{array}{l}2016 \text { Research Leap/Inovatus Services Ltd. } \\
\text { All rights reserved. } \\
\text { DOI: } 10.18775 / \text { jibrm.1849-8558.2015.21.3005 } \\
\text { URL: } \text { http://dx.doi.org/10.18775/jibrm.1849- } \\
\text { 8558.2015.21.3005 }\end{array}$ & $\begin{array}{l}\text { The purpose of this paper is to investigate socio-economic development condition and convergence } \\
\text { evaluation in the EU- } 28 \text { states in the context of the EU policy goals. The arm of this research is to } \\
\text { estimate socioeconomic disparities and convergence problems in the European states by applying } \\
\text { real valuations of well-being situations and economic development challenges in the EU member } \\
\text { states. The research methodology is based on the European Commission legitimate documents }\end{array}$ \\
\hline $\begin{array}{l}\text { Keywords: } \\
\text { Socio-Economic Policy } \\
\text { Convergence } \\
\text { Disparity } \\
\text { EU Strategy }\end{array}$ & $\begin{array}{l}\text { calculations and the socioeconomic forecasts analysis in the EU states. This research presents } \\
\text { information about different socioeconomic indicators, indexes, and scheme of information`s flows } \\
\text { for convergence level estimation. This study contains objectives and general outlines of period 2014- } \\
2020 \text { in the framework of Europe as a whole, as well its impact on the EU member states economies } \\
\text { and living conditions. Changes in the main socioeconomic concepts impact on EU convergence } \\
\text { policy and rapidity of convergence depends on the initial discrepancy of the development level in the } \\
\text { EU states. The efficiency of European convergence policy can also be improved by significant } \\
\text { economic growth and by a clever choice of the country-specific social activities. This research } \\
\text { investigates above information for social situations estimations in EU states as well as GDP growth, } \\
\text { unemployment, population's income level and different welfare indicators. The main results reflect } \\
\text { the overall economic situation valuation in the EU countries and present European convergence } \\
\text { policy's impact on social development in the European states. The conclusions contain socio- } \\
\text { economic situations appreciation in the context of European strategy goals and social inequality } \\
\text { problems clarification in the EU states. }\end{array}$ \\
\hline
\end{tabular}

\section{Introduction}

European convergence policy is a place-based policy which gives a role to each European state in the sense that it is not an obstacle to the optimal allocation of economic activity but can become a source of growth on its own. Recent economic theory confirms this approach in numerous case studies which show that convergence policy can make a difference. In fact, the EU has achieved impressive economic and social convergence.

The passing decade has emphasized the fight against poverty and exclusion, particularly within the EU strategy and its economic, social and environmental pillars. It set the challenge of making Europe "the most competitive and dynamic knowledge-based economy in the world, capable of sustainable economic growth with more and better jobs and greater social cohesion" and included modernization of the European social model, investing in people, and combating social exclusion. "Europe 2020" strategy includes the Platform against Poverty and Social Exclusion and the Agenda for New Skills and Jobs. Through its Social Investment Package, the Commission guides member states to modernize their welfare systems towards social investment throughout life. The package complements - the Employment Package, which sets out the way forward for a jobrich recovery; White Paper on Pensions, presenting a strategy for adequate, sustainable and safe pensions; and Youth Employment Package, which deals specifically with the situation of young people. This means in particular that labor markets and welfare systems need to function well and be sustainable in all euro area member states. Better labor market and social performance, as well as social cohesion, should be at the core of the new process of social convergence (European Commission, 2010. "Europe 2020").

The European strategy must ensure that policies are ranked on their effects on short and long-term growth, employment and income distribution, social impact and fiscal sustainability. Evidence shows that fiscal consolidation instruments can have a vastly different impact on equity and growth - such is the case of cuts in education, healthcare, and family policy. For future`s social development investigations and governmental decisions needs to be pragmatic approach into financing to create 
employment and reduce poverty level and social disparities in the national economy.

European national economies strategies have been related to the influence of several internal and external factors, and EU convergence process can guarantee political stability and sufficiently consistent implementation of economic and social development. Taking into account the actual socio-economic problems in the EU countries European convergence policy should provide more attention to countries with minimum income level and high income's disparity with a target to reduce inequalities between EU countries and contribute social situation improvement in the EU states.

\section{European Social and Economic Convergence Policies Concepts}

European convergence policy is an EU development policy. Convergence process in EU is trying providing recommendations for the future development with a target to achieve socioeconomic well-being in the European states.

The social policies are an integral part of the "Europe 2020" Strategy and European Commission also supports EU countries efforts to address their social challenges through the actions foreseen in the Platform against Poverty and Social Exclusion and Social Investment Package as well as the EU funds, in particular, the European Social Fund. The Commission works together with EU countries through the Social Protection Committee using the Open Method of Co-ordination in the areas of social inclusion, health care and long-term care and pensions (Social OMC). However, this is a voluntary process for political cooperation based on agreeing with common objectives and measuring progress towards these goals using common indicators. The process also involves close co-operation with stakeholders, including social partners and civil society (The Social protection committee, 2011).

European social policy priorities are already part of the European strategy, but they tend to be of a more generic nature in comparison to fiscal policy recommendations, which have specific numerical targets. The crisis pressured EU member states to pursue budget consolidation, which often led to indiscriminate cuts in social welfare systems as well as inordinate tax hikes on the working population.

In general, EU needs to augment the use of social indicators to better assess economic impact, both in the short- and long-term. The interplay between social and economic indicators can also serve as a tool to discourage countries from enacting indiscriminate cuts because it is the easiest way to bring budgets in line in the short-run, without understanding the scarring implications over time. The forecasts and opinion of the socioeconomic situation in EU states and its development analysis concerning issues of national policy improvement. The information`s flows for national convergence level estimation is outlined in Figure 1. The basic directions of the socioeconomic policy for the achievement of the established objectives and convergence are as follows:

- To reach macroeconomic stability;

- To create favorable preconditions for economic activities;

- To stimulate effective growth of national economy;

- To reduce social and economic disparities and ensure sustainable development.

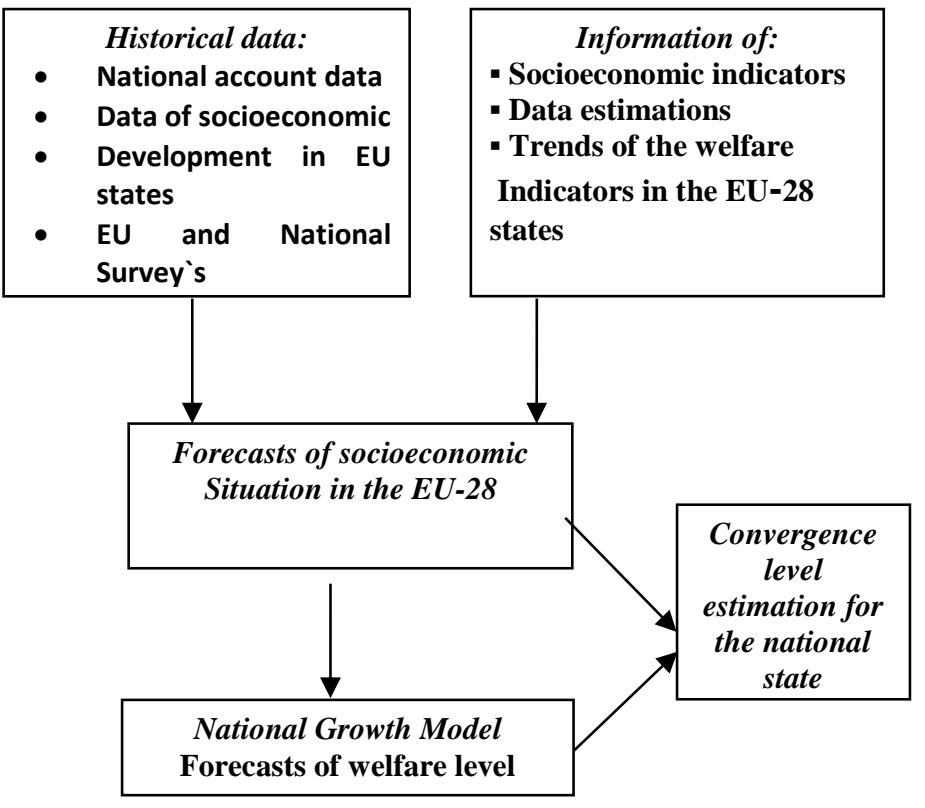

Figure 1: Scheme of information`s flows for convergence level estimation

Source: Author`s construction based on forecasting theory

The social conditions and employees also become more and more aware of the possibilities offered by the global market. It requires not only a structure of national social models but also a discussion on the strategic choice of countries concerning the social policy. The social structure undergoes not only quantitative changes but also qualitative changes decreasing disproportions between the social indicators of the national economy, which generates a range of problems in implementing national social development programs. Development of social processes in the EU states to a large extent connected with guidelines of strategic documents of national economy development and social situation in the countries, reflecting goals and tasks defined by EU programmatic documents for the areas of social development in the EU states.

The neo-classical theories of growth generate real social convergence. The standard growth model incorporates major factors of production and capital flows which influence on the economy as long-term strategic scenario. National socioeconomic growth model targets and forecasts are formulated by main priorities attainment for the economy and social policy. Trends for the recent years are taken as socioeconomic situation development strategy of the EU states which can be used for social estimation as income`s and pension`s policy improvement, labor market and education system optimization. 
Economic literature suggests that the term convergence in its economic essence describes the gradual elimination of disparities in the income level. Economic growth theory provides two types of the convergence: $\sigma$-convergence (sigma) and $\beta$-convergence (beta) (Barro, Sala-i-Martin, 2004).

The first kind serves as an indicator to measure whether the distribution of income across regions or countries has become less uneven over time. In contrast, $\beta$-convergence attempts to describe the mobility of income within the same distribution and predominantly serves to find out whether the convergence occurred because poorer regions and/or countries have grown faster than the rest.

The results from convergence analysis are usually used to test the validity of the two economic growth models- neoclassical and endogenous. The former one predicts $\beta$-convergence scenario. Convergence reflects the measure of progress, while Catching-up convergence regardless full, partial or absence of the capital mobility (Marzinotto B., 2012).

The Catching-up rate is calculated using the historical actual growth rate. It gives a framework for the ex-post analysis of the catch-up dynamism. In the case of negative catch-up rates the disparity between the country concerned and the EU average decreases, while the positive catch-up rate shows the increase of this difference. The negative rate indicates that there has been a reduction in the GDP gap between new member states and average GDP per capita of the EU-28. The positive catch up rate shows the actual growth of the rate.

The relationship between GDP growth and the level of income is considered as $\beta$-measures the distance to be traveled. The pace of Catching-up usually relates to $\beta$-convergence and is expressed as a Catching -up rate ( $\mathrm{R}$ Catch-up). For convergence estimation used new measure how to calculate country`s convergence of compared to average EU-28 level (Halmai P., Vasary V., 2010):

$$
R_{\text {Catch-up }}=100 \cdot \frac{\Delta\left(y_{i t}-y_{t}^{*}\right)}{\left(y_{i t-1}-y_{t-1}^{*}\right)}
$$

In the equation:

$\mathbf{y}_{\mathbf{i t}}$ - reflect the level of GDP per capita as PPS for country $i$ at a time t;

$\mathbf{y}_{\mathbf{t}}{ }^{*}$ - is the average for the $\mathrm{y}_{\mathrm{t}}$ of EU-28;

$\Delta$ - indicates the difference between $\mathrm{t}$ and $\mathrm{t}-1$;

$\mathbf{y}_{\mathbf{t}}{ }^{*}$ - is the weighted average of the EU-28.

Convergence policy must be connected with a judgment of the likely future evolution of the national economy, and it depends on a member state's domestic policy orientations after it has joined the euro area. Convergence processes for the EU countries must be based on the strong socioeconomic development and GDP, investment flows, new technologies and productivity growth. Trends of the recent years of development of the EU-28 economy, which shows steady GDP growth require social legislation improvement, income's growth, education system and labor market development.

Using $\beta$-convergence scenario by formula (1) and European statistics forecasts in 2016-2017 the primary calculations show that GDP growth and the current economic situation improved in EU at the whole and especial in Ireland, Latvia, Estonia, Lithuania, Slovakia, Poland, and Romania. Nevertheless, significant differences in levels between member countries continued to influence the current economic situation negatively. In several member states were significantly scaled back especially in Italy, France, Portugal and Finland. The GDP growth outlook for the next two years in the EU-28 increased slightly to an annual from 2.0 percent to 2.1 percent in 2020 .

Convergence processes for the EU states must be based on the strong economic growth of GDP per capita. Euro area real GDP is forecast to grow by $1.6 \%$ in 2015 , rising to $1.8 \%$ in 2016 and $1.9 \%$ in 2017 . For the EU as a whole, real GDP is expected to rise from $1.9 \%$ this year to $2.0 \%$ in 2016 and $2.1 \%$ in 2017 (European Commission data, 2015).

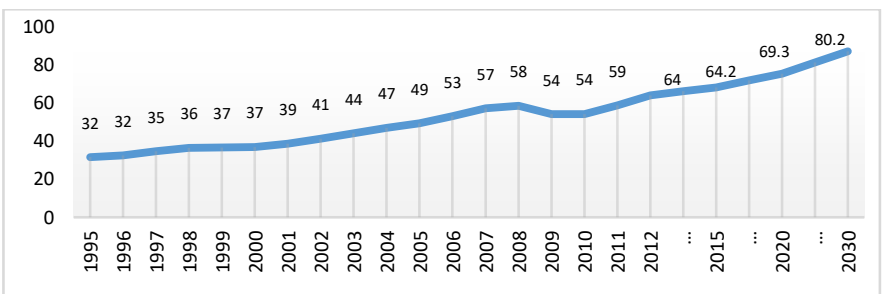

Figure 2: Differences between development of Latvia's GDP and EU-28 GDP

Source: Author`s construction based on convergence theory and Eurostat database. http://epp.eurostat.ec.europa.eu/portal/

For example, the situation in the social policy in Latvia continues improving. Latvia's economy growth is projected to increase from $2.4 \%$ in 2015 to $3 \%$ in 2016 and $3.3 \%$ in 2017 as domestic demand improves.

According to author's calculation based on the methodological framework of latest $\beta$-convergence scenario convergence theories, the level of Latvia's GDP per capita compared to EU-28 in 2015 was $64.2 \%$ and will increase up to $69.3 \%$ in 2020 and up to $80.2 \%$ in 2030 (see Figure 2).

Domestic demand is projected to be the main growth driver over the forecast horizon, and steadily rising income growth supports private consumption. Risks to the GDP forecast are related to the government's ability to deliver on the revenue measures, unexpected spending pressures and overruns, as well as the uncertain growth outlook (European Commission - Press release, 2015).

The process of real economic convergence suggests Catching- up in standards of living in new member states with those of the old 
EU member states and describes the gradual elimination of disparities in the income level. Catching-up and convergence process in the European Union is based on economic growth. This process, however, is usually accompanied by a rise in price levels, which is known as nominal convergence. The inverse relationship between growth and the level of income is considered a $\beta$ convergence scenario. If this factor is present, poorer countries get closer to the richer ones.

\section{Measurements of socioeconomic disparity in the EU states}

Term disparity is a multi-faceted phenomenon, which can have various origins and causes. According to Eurostat definitions and explanations, the term "inequality" refers to disparities in the distribution of monetary resources within or between populations. Socioeconomic inequality has been rising in most EU countries over the past ten years. Europe, as part of the "Europe 2020" strategy, has committed itself to lifting 20 million Europeans out of poverty and inequality, which is interconnected with poverty and social exclusion.

The main principle for living standards is growing and welfare increasing can be defined as real observance proportions between indicators of productivity, wages and inflation`s annual growth. Social conditions determined by the national economy development level, the number of population and level of urbanization, the geographical location, availability of infrastructure.

The socioeconomic situation is influenced by the GDP level and an economic structure of the national economy, which is determined by products offered by sectors and the total consumer's income and demand levels, labor force skills and education, but also a discussion on the strategic choice of countries national policy. Social standards can be compared by measuring the price of a range of goods and services in each country relative to income, using a common national currency called the purchasing power standard (PPS).

Comparing GDP per capita in PPS provides an overview of living standards across the EU. The EU strives to improve living standards by protecting the environment, encouraging job creation, reducing regional disparities and connecting formerly isolated areas by developing cross-border infrastructure. This indicates the need for more structural reform to remove rigidities in the allocations of resources, which is essential to raise living standards. The real situation in EU states by main convergence indicator as the GDP per capita last years can illustrate in Table 1.

The convergence in the EU during the past decades showed a relatively steady pace. The social situation is influenced by the GDP level, economic structure of the national economy, the total consumer's income and demand levels, labor force skills and education. At the same time future projection shall be based on the GDP potential growth rate, but now forecasts of social development based on GDP per capita at purchasing power standard.

Table 1: GDP per capita in the EU countries (GDP in PPS EU$28=100, \%, 2015)$

\begin{tabular}{|c|l|l|c|}
\hline $\begin{array}{c}\text { GDP per } \\
\text { capita } \\
\text { in PPS }\end{array}$ & Country & Country & $\begin{array}{c}\text { GDP per } \\
\text { capita } \\
\text { in PPS }\end{array}$ \\
\hline 45 & Cyprus (CY) & Bulgaria (BG) & $\mathbf{8 5}$ \\
\hline 54 & Spain (ES) & Romania (RO) & 93 \\
\hline 64 & Italy (IT) & Latvia (LV) & 97 \\
\hline 59 & United Kingdom (U) & Croatia (HR) & 108 \\
\hline 68 & France (FR) & Poland (PL) & 107 \\
\hline 68 & Finland (FI) & Hungary (HU) & 110 \\
\hline 74 & Belgium (BE) & Lithuania (LT) & 119 \\
\hline 73 & Germany (GE) & Estonia (EE) & 124 \\
\hline 76 & Sweden (SE) & Slovakia (SK) & 124 \\
\hline 78 & Denmark (DK) & Portugal (PT) & 124 \\
\hline 72 & Ireland (IL) & Greece (EL) & 132 \\
\hline 84 & Netherlands (NL) & Czech Republic (c & 130 \\
\hline 83 & Austria (AT) & Slovenia (SI) & 128 \\
\hline 85 & Luxembourg (LU) & Malta (MT) & 263 \\
\hline
\end{tabular}

Source: Calculation based on Eurostat and European Commission data 2015. European Forecast Autumn 2015. htpp://europa.eu/rapid/press-release,

htpp://ec.europa.eu/eurostat/tgm/table, 2015.

The convergence in the EU during the past decades showed a relatively steady pace. The social situation is influenced by the GDP level, economic structure of the national economy, the total consumer`s income and demand levels, labor force skills and education. At the same time future projection shall be based on the GDP potential growth rate, but now forecasts of social development based on GDP per capita at purchasing power standard.

In EU much attention is currently being paid to the consequences of inequality, such as poverty and lack of social cohesion, and policy interventions tend to focus on how to redress these outcomes through tax instruments instead of addressing the underlying causes. However, relying solely on taxing more and spending more can only be a temporary measure, which is not a solution to redress inequality in the long- run. The EU strives to improve living standards by protecting the environment, job creation, reducing regional social disparities. Progress supports policy development work in fallowing five areas: 1) employment, 2) social inclusion and social protection, 3) working conditions, 4) anti-discrimination, 5) gender equality.

The disparity can be defined and measured as a particular resource is distributed across the whole society, while economic inequality means primarily differences in earnings and incomes, social inequality relates to differences in access to social commodities including education and health care, but also social and institutional networks. The multidimensional term social exclusion relating many spheres: 
In economic field - livelihoods, employment, housing, property, poverty and material deprivation;

In social field - education, health, personal contacts, respect;

In the political field - civic engagement, citizenship, migration.

While the EU has a clear role, and competencies, in reducing EUwide inequality, still reducing inequality at national level within EU countries is a precondition for reducing European inequality. This might be a sign that tackling inequality has not featured prominently enough on the policy agenda and that social policies have not been efficient enough to redress the persistent tendency towards a worsening of inequality.

Income or earnings disparity is moderated by social transfers, taxes, and benefits but these redistributive mechanisms have not prevented income inequality from rising over the past decades. One of the reasons for such an increase may also be that moving from household earnings to market income requires broadening the analysis to include self-employment and capital income, where the concentration among individuals is much higher than that of household earnings.

Table 2: Monthly minimum wages in the EU countries 2015,

\begin{tabular}{|l|c|l|c|}
\hline Country & $\begin{array}{c}\text { Monthly } \\
\text { minimum } \\
\text { wage, } \\
\text { euro }\end{array}$ & Country & $\begin{array}{c}\text { Monthly } \\
\text { minimum } \\
\text { wage, } \\
\text { euro }\end{array}$ \\
\hline Bulgaria (BG) & 194.2 & Greece (EL) & 683.7 \\
\hline Romania (RO) & 234.7 & Malta (MT) & 720.4 \\
\hline Lithuania (LT) & 325.0 & Spain (ES) & 756.7 \\
\hline Latvia (LV) & 360.0 & Slovenia (SI) & 790.9 \\
\hline Croatia (HR) & 398.9 & France (FR) & 1457.5 \\
\hline Hungary (HU) & 333.4 & Ireland (IL) & 1461.8 \\
\hline $\begin{array}{l}\text { Czech Republic } \\
\text { (CZ) }\end{array}$ & 337.5 & Germany (GE) & 1473.0 \\
\hline Slovakia (SK) & 380.0 & Belgium & 1501.8 \\
\hline Estonia (EE) & 390.0 & Netherlands (NL) & 1507.8 \\
\hline Poland (PL) & 417.5 & $\begin{array}{l}\text { United Kingdom } \\
\text { (UK) }\end{array}$ & 1509.7 \\
\hline Portugal (PT) & $\mathbf{5 8 9 . 1}$ & Luxembourg (LU) & 1922.9 \\
\hline
\end{tabular}

Source: calculation based on Eurostat and European Commission data 2015. European Forecast Autumn2015.

htpp://europa.eu/rapid/press-release,

htpp://ec.europa.eu/eurostat/tgm/table, 2015.

The national minimum wages on 2015 of the EU-28 member states was ranged from $€ 194$ per month in Bulgaria to $€ 1923$ in Luxembourg. However, when adjusted for differences in purchasing power, the disparities between EU countries are reduced from a ratio of $\mathbf{1}$ to $\mathbf{1 0}$ in euro to a ratio of $\mathbf{1}$ to $\mathbf{4}$ in purchasing power standards PPS (see Table 2).

The Gini coefficient captures differences in inequality in household incomes over time or between different regions and countries. It ranges between 0 (absence of inequality) and 1 (total inequality); - quintile ratios measure disparities in earnings between high and low paid workers. Frequently used are the $80 / 20$ quintile ratio, which contrasts the top $20 \%$ of earners with the lowest $20 \%$. The gap between rich and poor, which is usually measured as the ratio of the top $20 \%$ of the population to the bottom $20 \%$ on the income scale, has been steadily growing from a ratio of 4.8 in 2008 to 7.2 in 2015 across the EU as a whole (European Commission data, 2015).

Socioeconomic inequality refers to disparities in a range of economic and social resources that have an impact on individuals' well-being, such as income, education, and health. In a nutshell, The EU uses an "at-risk of poverty" measure, defined as "those living below $60 \%$ national median equalized disposable income", as not all those with low incomes are necessarily poor. The unit of measurement is households adjusted for household size: equalized incomes are defined as the household's total disposable income divided by its "equivalent size". Europe, as part of the Europe 2020 Strategy, has committed itself to lifting 20 million Europeans out of poverty which is interconnected with poverty and social exclusion: the more unequal a society is, the more widespread poverty and social exclusion tend to be.

European statistics show that in $201524.5 \%$ or 121952000 people of all the EU population are at risk of poverty or social exclusion and this includes $27.6 \%$ of all children in Europe, $18.3 \%$ of those is over 65 age old and $25.3 \%$ of adults (see Table $3)$.

The at-risk-of-poverty rate or the share of the population below the poverty line increased during the period when the total income of the population was increasing substantially, and the unemployment rate was comparatively low. It means that the increase in income of the population was unequal and not all people were able to adapt to the changes and benefit from the growth opportunities. Poverty and social exclusion among those of working age (18-64 years) have increased significantly in twothirds of EU member states as a combined result of rising levels of unemployment and in-work poverty. The likelihood of entering into and exiting from poverty varies greatly across EU member states. In some countries, a significant proportion of the population is trapped in persistent poverty, while in others they succeed in escaping poverty but often only temporarily.

Available data show that social mobility varies significantly across EU countries. For example, the UK is highly unequal but also mobile, while in Germany there is mobility but only within the original socioeconomic group, making it hard to move from a lower to a higher category.

Increasing in the private consumption will depend on changes in personal income. The social and personal income taxes in EU is planned to be gradually decreased from 2016, and this changes can increase to personal incomes and foster growth of private consumption. However, the still high unemployment rate does not allow to increase wages, and the medium-term changes in wages are unlikely to exceed the increase in productivity. 
Table 3: The at-risk-of-poverty rate or social exclusion in the EU States (\% of total population, 2015)

\begin{tabular}{|l|l|l|l|}
\hline Country & & Country & \\
\hline Bulgaria (BG) & 40.1 & Cyprus (CY) & $\mathbf{2 7 . 8}$ \\
\hline Romania (RO) & 40.4 & Spain (ES) & 27.3 \\
\hline Latvia (LV) & 35.1 & Italy (IT) & 28.4 \\
\hline Croatia (HR) & 29.9 & United Kingdom & $\mathbf{2 4 . 8}$ \\
\hline Poland (PL) & 25.8 & France (FR) & 18.1 \\
\hline Hungary (HU) & 33.5 & Finland (FI) & 16.0 \\
\hline Lithuania (LT) & 30.8 & Belgium (BE) & $\mathbf{2 0 . 8}$ \\
\hline Estonia (EE) & 23.5 & Germany (GE) & $\mathbf{2 0 . 3}$ \\
\hline Slovakia (SK) & 19.8 & Sweden (SE) & 16.4 \\
\hline Portugal (PT) & 27.4 & Denmark (DK) & 18.9 \\
\hline Greece (EL) & 35.7 & Ireland (IL) & 30.0 \\
\hline $\begin{array}{l}\text { Czech Republic } \\
\text { (CZ) }\end{array}$ & 14.6 & Netherlands (NL) & 15.9 \\
\hline Slovenia (SI) & 20.4 & Austria (AT) & 18.8 \\
\hline Malta (MT) & 24.0 & Luxembourg (LU) & 19.0 \\
\hline
\end{tabular}

Source: calculation based on Eurostat and European Commission data 2015. European Forecast Autumn 2015,

htpp://ec.europa.eu/eurostat/tgm/table.

htpp://europa.eu/rapid/press-release, 2015

Domestic demand is strengthening in most euro area Member States recent years, and economic activity should rise across the EU in 2016 and 2017. Private consumption is growing as a result of rising nominal incomes and low inflation. Investment is also expected to strengthen somewhat on the back of rising disposable incomes for households, improving profit margins of corporations and favorable financing conditions.

The unemployment rate in the EU in 2015 reached to $10.5 \%$. The social costs inflicted by the crisis continue to weigh heavily on the euro area's performance and internal cohesion. They also reveal a dramatic divergence between EU member states - be it in unemployment rates, which vary from $4.7 \%$ in Germany to $25.7 \%$ in Greece, or the share of low-skilled in the workforce, which ranges from $15.1 \%$ in Estonia to $56.3 \%$ in Portugal. Such divergence is not sustainable in the context of EU targets for social development (Eurostat and European Commission data, 2015). Income and living conditions database European Forecast Autumn 2015). One in five long-term unemployed EU citizens has never worked, three-quarters of them being below 35 years of age. This creates a strong risk of marginalization, exacerbated by the low demographic growth of the continent, which is pushing more and more European societies. Long-term unemployment (i.e. individuals unemployed for 12 months or more) has increased in most member states in recent years, doubling between 2008 and 2015 at EU level. The problem, however, is particularly acute in some countries, notably Spain, Cyprus, and Greece. In recent months, very long-term unemployment (for 24 months or more) has continued to increase, while overall unemployment has only modestly declined. Men, youth, and lowskilled workers are more vulnerable to long-term unemployment, as well as those employed in declining occupations and sectors, whose skills often need upgrading (see Table 4).

Dynamic and inclusive labor markets are key for convergence high-performing, inclusive labor markets need to be at the heart of the social dimension of EU. A modern social policy must be both about enabling people to make the most out of their talent as well as ensuring equity in opportunity. Only effective social policy and labor markets development in European states can successfully master the challenge of overcoming mass unemployment and growing social exclusion. The European Union is committed to the principle of the free movement of people within its frontiers, which is central to the concept of EU citizenship. But this principle has given rise to concerns caused by the inclusion of more Eastern European countries with much lower wages. Many people in Germany, Britain, the Netherlands, Austria and other "old EU" members, particularly those with low skills in precarious low-wage jobs, who are threatened by unemployment and disadvantaged in housing markets, fear the consequences of the unlimited movement of workers from the East.

Table 4: Unemployment rate (\%) in the EU States 2007 - 2017

\begin{tabular}{|l|c|c|c|c|c|c|c|}
\hline Country & $\begin{array}{c}\mathbf{2 0 0 7 -} \\
\mathbf{2 0 1 1}\end{array}$ & $\mathbf{2 0 1 2}$ & $\mathbf{2 0 1 3}$ & $\mathbf{2 0 1 4}$ & $\mathbf{2 0 1 5}$ & $\begin{array}{c}\mathbf{2 0 1 6} \\
\text { f }\end{array}$ & $\begin{array}{c}\mathbf{2 0 1 7} \\
\text { f }\end{array}$ \\
\hline EU & 8.5 & 10.5 & 10.9 & 10.2 & 10.5 & 9.2 & 8.9 \\
\hline Germany & 7.3 & 5.4 & 5.2 & 5.0 & 4.7 & 4.9 & 5.2 \\
\hline Estonia & 10.5 & 10.0 & 8.6 & 7.4 & 6.5 & 6.5 & 7.6 \\
\hline Latvia & 13.4 & 15.0 & 11.9 & 10.8 & 9.8 & 9.5 & 8.8 \\
\hline Lithuania & 11.4 & 13.4 & 11.8 & 10.7 & 9.4 & 8.6 & 8.1 \\
\hline Spain & 15.7 & 24.8 & 26.1 & 24.5 & 22.3 & 20.5 & 19.0 \\
\hline France & 8.6 & 9.8 & 10.3 & 10.3 & 10.4 & 10.4 & 10.2 \\
\hline Italy & 7.5 & 10.7 & 12.1 & 12.7 & 12.2 & 11.8 & 11.6 \\
\hline Portugal & 10.7 & 15.8 & 16.4 & 14.1 & 12.6 & 11.7 & 10.8 \\
\hline Sweden & 7.4 & 8.0 & 8.0 & 7.9 & 7.7 & 7.7 & 7.4 \\
\hline $\begin{array}{l}\text { United } \\
\text { Kingdom }\end{array}$ & 6.9 & 7.9 & 7.6 & 6.1 & 5.4 & 5.4 & 5.5 \\
\hline Source & & & & & & \\
\hline
\end{tabular}

Source: htpp://europa.eu/rapid/press-release, 2015, calculation based on Eurostat and European Commission data 2015 European Forecast Autumn 2015, htpp://ec.europa.eu/eurostat/tgm/table.

They fear that their wage and job prospects may be undermined by the employment of immigrant workers at lower salaries, that incoming migrants may push up rents and property prices and that migrants may impose greater burdens on the welfare state, particularly if migrants have lower skills and wages than the indigenous population, are more prone to unemployment, and likely to pay lower taxes. The debate about migration and public policy has become highly charged for the European community.

The 2015 review of Employment and Social Developments demonstrates an urgent need to increase efforts to return to convergence, both economic and social. Jobs and Growth remain EU number one priority. Following recent initiatives on the integration of the long-term unemployed, the Youth Guarantee and the Youth Employment Initiative, EU states will take forward work on proposals for a European Pillar of Social Rights, on labor mobility and skills. EU will continue working side by side with the 
social partners to achieve an inclusive recovery and to make a social progress for all Europe countries a reality (European Commission - Press release, 2015).

The EU countries convergence has been at risk because states and its regions are affected in different ways and to varied degrees of intensity. The mechanisms in social policy are not sufficient about future progress in the European integration and concerning the need to reduce socioeconomic inequality. The European budget as the financial instrument promotes economic, social and regional cohesion at the national and EU levels. Consequently, all policies and all community budget spending will have to be more effective, in particular, 2014-2020. One of the main steps of EU policy development shoud be combined competitive economies that can innovate and succeed in an increasingly globalized world, with a high level of convergence between EU states.

\section{Conclusions, proposals, recommendations}

1. EU national economies strategies have been related to the influence of several internal and external factors. EU convergence process can guarantee political stability and sufficiently consistent implementation of economic and social strategies and programs. European social policy shared competence between the GDP annual growth rates regarding economic development are incentive structures for individuals, firms and countries need to be rethought to better link social and economic outcomes.

2. Trends of the recent years (2014-2020) of EU states economies are taken as the important priorities EU and its member states and includes new objectives for social matters like full employment, social progress, the fight against social exclusion and social protection of EU citizens.

3. The EU states disparities in developing of social legislation, the situation in the income`s growth, pension`s policy improving, education system and labor market development.

4. Socioeconomic convergence of the EU new member states has been considered as one of the most important economic development targets in the EU. It supports job creation, competitiveness, economic growth, improved quality of life and modernizing social protection.

5. Taking into account the actual problems of a social situation in the EU countries, it is important for the national economies to open market and companies producing goods with a high value added, as well as to use modern information technologies in their work. The socioeconomic policy improvement in general connected with investment flows, new technologies and productivity growth and more flexible and balanced labor market, taking into account the actual demographic situation of the society and national economies competitiveness EU and world market.

6. The European Union aims to reduce the economic, social and territorial disparities that still exist between Europe's states. Leaving these disparities in place would undermine some of the cornerstones of the EU, including its large single market and its currency - euro. Best Protection from poverty human capital is one of Europe's undisputed strengths, but emerging economies are quickly catching-up, threatening to erode our basis of competitive advantage and source of high living standards.

The necessity for the EU to move towards harmonization of socioeconomic policy and a harmonization of minimum social standards is becoming more obvious. Convergence policy must bet connected with a judgment of the likely future evolution of the national economy.

The effectiveness of European convergence policy can also be improved by significant economic growth and by a clever choice of the country-specific social activities. Increasing EU economic integration at the regional or states level may have contributed to enclose of regional disparities by strengthening the more dynamic regions of the country, but at the same time, it can determine substantially growth prospects at the national level.

National economies will need to recognize that labor market and lower corporate taxes are the only competitive tools if they want to attract new capital - the key to lower unemployment, in the longer-term. In the short-term will mean that the restructuring of EU economy will continue with the innovative sector share increase into GDP.

\section{References}

- Barro, R.J., Sala-i-Martin, X., 2004. Economic growth. 2nd Ed. The MIT Press, (pp .44-51, 74-76), England, London.

- Barro, R. J. , Lee, J.-W., 2010. A new data set of educational attainment in the world, 1950-2010. Working Paper, No. 15902, 2010. http://www.nber.org/papers/w15902

- Bertola, Giuseppe, John Driffill, Harold James, HansWerner Sinn, Jan-Egbert Sturm and Ákos Valentinyi, 2015, "Summary", EEAG Report on the European Economy 2015, 2015, pp. 8-12

- Checherita C., Nickel C., Rother P., 2009. The Role of Fiscal Transfers for Regional Economic Convergence in Europe, ECB Working Paper, pp. 10-29.

- CESifo Economic Studies, vol. 2014-2015: http://www.cesifo-group.de/ifoHome.html

- Convergence Report on Latvia, 2013. European Economy Nr. 3/2013.pp. 45-46. http://ec.europa.eu/economy_finance

- Dall'erba S. and Le Gallo J., 2008. Regional convergence and the impact of European structural funds 1989-1999: A Spatial Econometric Analysis, Papers in Regional Science, 87(2), pp. 219-244, CrossRef

- Dauderstadt, M., Keltek, C., 2012: Inequality is growing again in Europe: http://library.fes.de/pdffiles/id/ipa/09331.pdf;

- Dauderstaedt, M., 2010: Europe's hidden inequality, 05/10/2010, http://www.socialeurope.eu/2010/10/europes-hidden-inequality/ 
- David M. Trubek and Louise G., 2015. Hard and Soft Law in the Construction of Social Europe: the Role of the Open
Method
of
Co-ordination:

http://eucenter.wisc.edu/Publications/trubekTrubekELJ.pd $\mathrm{f}$;

- Decent Life for All: Ending Poverty and Giving the World a Sustainable Future, COM (2013) 92 final (p.6): http://ec.europa.eu/europe 2020/

- Directorate-General for Economic and Financial Affairs, 2015. European Forecast Autumn 2015. European Economy. http://ec.europa.eu/economy_finance

- European Commission - Press release, 2015. Economic Forecast: Moderate recovery despite challenges, 2015. htpp://europa.eu/rapid/press-release

- European Commission, 2013. Country - Specific Recommendations-Final Version, Approved by the Council: http://ec.europa.eu/europa2020/europa-2020-inyour-country/latvia

- European Commission, 2010. "Europe 2020": A European strategy for smart, sustainable and inclusive growth, 2020: http://ec.europa.eu/eu2020/pdf/

- European Commission data, 2015. Income and living conditions database European Forecast Autumn 2015, htpp://europa.eu/rapid/press-release

- Eurostat, 2016. htpp://ec.europa.eu/eurostat/tgm/table, 2016.

- Eurostat, 2014. Income and living conditions database. http://epp.eurostat.ec.europa.eu/portal/ page/portal/income_social_inclusion_living_conditions/da ta/database

- Ifo World Economic Survey (WES) of the 4th quarter 2015. Ifo World Economic Climate Results., http://www.cesifo-group.de/ifoHome.html

- Halmai, P., Vasary, V., 2010. Real Convergence in the new Member States of the European Union. The European Journal of Comparative Economics, Vol.7, Nr.1, pp.229253.

- Marzinoto B., 2012.The growth effects of EU cohesion policy: A Meta-analysis. Brugel Working Paper 2012/14) pp.17.

- Stiglitz J., 2009. Report of the commission on the measurement of economic performance end social progress http://www.stiglitz-sen-fitoussi.fr/en/index.htm

- The Social protection committee, 2011. The social dimension of the Europe 2020 Strategy. The rise of income inequality amongst rich countries: http://inequalitywatch.eu/spip.php?article58

- World Bank, 2015. "What's next in Ageing Europe: Ageing with Growth in Central Europe and the Baltics," http://www. Worldbank.org/content/dam/World bank/Publications/ECA/ 